\title{
MAKNA KOMUNIKASI DI BALIK MAKANAN TRADISIONAL
}

\author{
Chusmeru \\ Fakultas ilmu Sosial dan Ilmu Politik \\ Universitas Jenderal Soedirman \\ chusmeru@yahoo.com
}

\begin{abstract}
ABSTRAK
Indonesia memiliki beragam makanan tradisional yang khas di berbagai daerah. Penelitian ini bertujuan untuk mengetahui ragam makanan tradisional di Indonesia dan makna komunikasi di balik makanan tradisional tersebut. Penelitian dilakukan dengan metode deskriptif kulatitatif dengan informan mahasiswa yang dipilih dengan teknik purporsive sampling. Pemilihan informan didasarkan pada asal daerah mahasiswa yang berasal dari Jawa Tengah, Jawa Barat, Jawa Timur, dan Sumatera Utara. Hasil penelitian menjukkan, bahwa meskipun makanan import banyak terdapat di Indonesia, namun makanan tradisional berbagai daerah masih dapat ditemui dan tidak ditinggalkan oleh masyarakat. Makanan tradisional berbagai daerah masih bisa bertahan, karena memiliki makna komunikasi di masayarakat. Makna yang terdapat di balik makanan tradisional adalah sebagai bagian dari ritual siklus kehidupan, simbol persaudaraan, serta akulturasi dua budaya yang berbeda.
\end{abstract}

Kata kunci: makanan tradisional, makna komunikasi, akulturasi budaya

\section{A. PENDAHULUAN}

Setiap negara, masyarakat, atau daerah memiliki makanan tradisional yang khas, yang dapat membedakan antara satu negara atau daerah dengan yang lain. Kekhasan itu dapat berkaitan dengan bahan baku, rasa, cara memasak, warna, bentuk, cara menyajikan, dan cara menyantapnya. Oleh sebab itu makanan tradisional merupakan bagian dari budaya suatu negara atau daerah. 
Makanan khas suatu daerah atau kuliner tradisional dianggap penting, selain sebagai ciri khas suatu daerah juga menjadi salah satu daya tarik wisata. Menurut Wikipedia, culinary is difined as something related to, or connected with, cooking or ktchen. Kuliner berhubungan dengan memasak atau dapur. Dalam perkembangannya, kuliner sering dikaitkan dengan masakan khas suatu daerah atau makanan yang memiliki keunikan dan citarasa tersendiri. ( Chusmeru, 2009: 88 )

Pentingnya makanan dalam kehidupan manusia tak terbantahkan. Bukan hanya sebagai produksi organisme untuk mempertahankan hidup, makanan adalah juga fenomena kebudayaan. Menurut Foster dan Anderson, simbolisasi makanan mencakup ikatan sosial, solidaritas kelompok, ketenangan jiwa, dan simbolisme makanan dalam bahasa. Makanan jelas penting untuk kehidupan biologis, namun ia juga penting dalam hubungan sosial. Kerap kita temukan makanan sering ditautkan dengan suatu kepercayaan, keyakinan atau takhayul. Ini menunjukan kuatnya arti simbolik makanan itu ( Malagina, 2008: 14) .

Seiring dengan kemajuan era keterbukaan komunikasi, makanan tradisional juga mengalamai dampak buruk globalisasi, yaitu keterpinggiran. Makanan tradisional mulai ditinggalkan oleh masyarakat lokal. Padahal makanan tradisional bukan hanya berfungsi sebagai bahan makanan pokok saja, tetapi juga sebagai simbol identitas suatu daerah. ( Nurhayati, 2013: 8 )

Meski demikian, di tengah serbuan menu makanan internasional, dalam beberapa tahun terakhir bermunculan menu dan tempat makan yang menyediakan makanan khas daerah seperti Ayang Goreng Kalasan, Gado-Gado, Sate Senayan, Rumah Makan Ampera, Rumah Makan Bumbu Desa, dan sebagainya. Mereka bersanding dengan Pizza Hut, KFC, dan Mc Donald. Bahkan, di pusat perbelanjaan FX Senayan setiap bulan digelar menu makanan khas Indonesia dengan tema 7 days of Indonesia Traditional Food Stalls. (Murwani, 2012: 304)

Makanan, baik yang tradisional maupun modern, memang bukan sekadar untuk pemenuhan 


\section{MAKNA KOMUNIKASI DI BALIK MAKANAN TRADISIONAL}

kebutuhan biologis seseorang.

Makanan dan orientasi orang untuk mengkonsumsi makanan juga dapat menjadi gaya hidup, identitas, maupun produk budaya suatu daerah. Sebagaimana dikatakan Lee ( dalam Murwani, 2012: 302), konsumsi tidak hanya semata-mata merupakan tindakan yang wajar untuk memenuhi kebutuhan seseorang, akan tetapi lebih dari itu, konsumsi digunakan sebagai alat komunikasi kepada orang lain untuk menunjukkan identitas, posisi sosial maupun gaya hidupnya.

Penelitian tentang fungsi komunikasi makanan tradisional menjadi penting untuk dilakukan agar masyarakat Indonesia masih mengenali, mencintai, dan ikut melestarikan makanan daerahnya masing-masing. Makanan tradisional sebagai produk budaya juga perlu dipertahankan keberadaanya agar tidak tergusur oleh produk-produk makanan impor yang lebih menawarkan gaya hidup hedonis dibanding kearifan lokal. Penelitian makanan tradisional juga penting untuk melihat sejauhmana masyarakat kita masih mencintai identitas daerahnya.
B. RUMUSAN MASALAH

1. Setiap daerah di Indonesia memiliki makanan tradisional yang khas dan dapat menjadi identitas sosial budaya daerah. Seperti apa ragam makanan tradisional yang ada di berapa daerah di Indonesia?

2. Makanan tradisional selain dimanfaatkan untuk pemenuhan kebutuhan biologis juga memiliki makna komunikasinya. Apa saja makna komunikasi yang terdapat dalam makanan tradisional di Indonesia?

\section{TINJAUAN PUSTAKA}

1. Makanan Tradisional

Makanan pada umumnya dipandang sebagai salah satu faktor pemenuhan kebutuhan biologis manusia. Makanan juga berfungsi sosial, budaya, politik, dan ekonomis. Bahkan makanan dapat dipandang sebagai fungsi magis atau religi. Banyak simbol religi atau magis yang dikaitkan dengan makanan. Dalam agama Islam, kambing sering dikaitkan dengan upacara penting siklus kehidupan, seperti upacara selamatan kelahiran bayi atau khitanan. Anggur dalam agama Katolik diibaratkan darah 
MAKNA KOMUNIKASI DI BALIK MAKANAN TRADISIONAL

Kristus, dan roti sebagai tubuhnya.

Masyarakat Jawa juga melakukan upacara selamatan dengan menghidangkan nasi tumpeng dan nasi kuning ( Almatsier dalam Mapandin, 2006: 47 )

Selanjutnya Almatsier ( dalam Mapandin, 2006: 47 ) menyatakan makanan merupakan media penting dalam upaya manusia berhubungan satu sama lain. Hubungan antaranggota dalam rumah tangga terasa lebih hangat ketika makan bersama. Dalam rumah tangga besar, pertemuan berkala untuk memelihara dan mempererat tali silaturahmi juga dilakukan dengan acara makan bersama.

Kemajemukan agama, etnis, dan budaya yang ada di Indonesia menyebabkan beragamnya makanan khas atau makanan tradisional. Kecenderungan untuk mengkonsumsi makanan khas daerah atau makanan tradisional menurut Bourdieu ( dalam Murwani, 2012: 309 ) disebabkan adanya internal forces, atau biasa disebut habitus. Habitus merupakan proses pembatinan atau perekaman yang membekas dalam benak akibat anjuran berulang-ulang dalam waktu lama, sejak anak-anak melalui lingkungan keluarga

maupun

lembaga pendidikan.

Makanan tradisonal sebagai bagian dari budaya masyarakat juga dapat dikembangkan sebagai produk wisata. Salah satu komponen budaya Bali yang menarik wisatawan, misalnya, adalah makanan tradisional. Makanan tradisional Bali adalah makanan khas daerah Bali yang telah dikenal dan dibuat dengan cara sederhana dan secara turun temurun digunakan oleh masyarakat Bali dalam memenuhi kebutuhan hidupnya. Penghayatan nilai-nilai luhur yang terkandung dalam makanan tradisional Bali dapat meningkatkan jatidiri budaya Bali sendiri. ( Trisna Eka Putri, 2010: 98) Selanjutnya Trisna Eka Putri menjelaskan, sejak pariwisata budaya berkembang di Bali, makanan tradisional Bali ikut pula menjadi salah satu hal yang diminati oleh wisatawan. Berbagai upaya telah dilakukan untuk meningkatkan mutu makanan tradisional Bali. Selain teknik pengolahan dan penerapan teknologi modern, makanan tradisional Bali juga dijual di rumah makan, restoran, dan hotel bertaraf internasional. 


\section{MAKNA KOMUNIKASI DI BALIK MAKANAN TRADISIONAL}

Makanan atau kuliner

merupakan kebutuhan dasar manusia yang tidak dapat terlepas dari kegiatan apa pun, termasuk dalam berwisata. Pentingya posisi kuliner dalam dunia pariwisata bukan hanya untuk pemenuhan kebutuhan wisatawan, namun makanan khas suatu daerah juga dapat menjadi branding daerah tersebut. Pantai Jimbaran di Bali, misalnya, identik dengan ikan bakar atau seafood, sajian babi guling dan ayam betutu dari daerah Gianyar dan Ubud, Siobak dari daerah Buleleng, atau Kintamani yang khas dengan ikan mujair. ( Sri Aryanti, 2016: 16)

Setiap masyarakat dan suku bangsa memiliki makanan tradisional yang khas. Kriteria makanan tradisional di masing-masing daerah adalah diolah menurut resep makanan atau komposisi bumbu yang telah dikenal dan diterapkan secara turun temurun dalam sistem keluarga atau masyarakat. Bahan baku untuk makanan tradisional tersedia setempat, baik merupakan hasil usaha tani sendiri maupun tersedia dalam sistem pasar setempat. Cara pengolahan juga spesifik menurut cara-cara yang telah dikembangkan oleh masyarakat setempat

Nurhayati, 2013: 9 )

2. Fungsi Komunikasi

Makanan tradisional sebagai produk sosial budaya masyarakat erat kaitan dengan komunikasi. Makanan dapat berfungsi untuk mengkomunikasikan status sosial seseorang di masyarakat. Makanan juga dapat berfungsi sebagai sarana untuk saling berkomunikasi sesama anggota masyarakat dalam suatu kegiatan. Makanan dapat pula menjadi identitas diri dan sosial masyarakat, yang akan menjelaskan tentang asal daerah seseorang. Ketika orang menyebut Rendang, maka kita dapat merujuk pada makanan yang berasal dari daerah Sumatera Barat. Begitu pun ketika orang menyantap makanan Gudeg, maka akan membayangkan bagaimana masyarakat Yogya mengolah masakan tersebut.

Komunikasi secara umum mempunyai empat fungsi, yaitu sebagai Komunikasi Sosial, Komunikasi Ekspresif, Komunikasi Ritual, dan Komunikasi Instrumental. Fungsi komunikasi sosial mengandung arti, bahwa komunikasi penting untuk membangun konsep diri, aktualisasi 
diri, kelangsungan hidup, memperoleh kebahagiaan, terhindar dari tekanan dan ketegangan melalui komunikasi yang menghibur dan menjalin hubungan dengan orang lain. Implisit dalam fungsi komunikasi sosial adalah fungsi komunikasi kultural. Pada satu sisi, komunikasi merupakan mekanisme untuk mensosialisasikan normanorma budaya masyarakat, dan pada sisi yang lain budaya menetapkan norma-norma komunikasi yang dianggap sesuai untuk suatu kelompok. ( Mulyana, 2013: 5-7)

Fungsi komunikasi ekspresif berkaitan dengan komunikasi sebagai instrument untuk menyampaikan perasaan-perasaan, terutama melalui pesan-pesan nonverbal. Perasaan sayang, peduli, rindu, simpati, gembira, sedih, takut, prihatin, marah, dan benci dapat disampaikan lewat kata-kata maupun perilaku nonverbal. ( Mulyana, 2013: 24 )

Fungsi komunikasi ritual biasanya dilakukan secara kolektif dalam suatu masyarakat. Suatu komunitas sering melakukan upacara-upacara berlainan sepanjang tahun dan sepanjang hidup, mulai dari upacara kelahiran, khitanan, ulang tahun, pertunangan, pernikahan, hinga upacara kematian.

Dalam acara-acara itu orang mengucapkan kata-kata atau menampilkan perilaku simbolik. Mereka yang berpartisipasi dalam bentuk komunikasi ritual tersebut menegaskan kembali komitmen mereka kepada tradisi keluarga, komunitas, suku, bangsa, negara, ideology, atau agama mereka. (Mulyana, 2013:27)

Komunikasi berfungsi secara instrumental ketika memiliki tujuan menginformasikan, mengajar, mendorong, mengubah sikap dan keyakinan, mengubah perilaku, dan menghibur. Secara instrumental, komunikasi digunakan untuk mencapai tujuan pribadi dan pekerjaan, baik tujuan jangka pendek maupun jangka panjang. Tujuan jangka pendek misalnya untuk memperoleh pujian, menumbuhkan kesan yang baik serta untuk mendapatkan keuntungan material, ekonomi, dan politik. Tujuan jangka panjang dapat diraih lewat keahlian komunikasi, misalnya keahlian berpidato, berunding, berbahasa asing, atau pun keahlian menulis. ( Mulyana, 2013: 34 )

Menurut Judy C. Pearson dan Paul E. Nelson (dalam Ngalimun, 2017: 32), 


\section{MAKNA KOMUNIKASI DI BALIK MAKANAN TRADISIONAL}

komunikasi memiliki fungsi untuk kelangsungan hidup diri sendiri dan kelangsungan hidup bermasyarakat. Untuk kelangsungan hidup diri sendiri, misalnya dalam meningkatkan kesadaran pribadi, keselamatan jiwa, menampilkan diri sendiri kepada orang lain, dan untuk menggapai ambisi pribadi. Sedangkan fungsi untuk kelangsungan hidup bermasyarakat, yaitu untuk memperbaiki hubngan sosial masyarakat dan mengembangkan keberadaan suatu masyarakat.

Sebagai proses sosial, komunikasi memiliki fungsi menghubungkan berbagai komponen di masyarakat, baik individu maupun lembaga sosial. Komunikasi juga berfungsi sebagai manifestasi kontrol sosial di masyarakat. Berbagai nilai, norma, peran, cara, kebiasaan, tata kelakuan, dan adat dalam masyarakat yang mengalami penyimpangan akan dikontrol dengan komunikasi. Tidak dapat dipungkiri, komunikasi berperan dalam sosialisasi nilai ke masyarakat. Bagaimana sebuah norma kesopanan disosialisasikan kepada generasi muda dengan contoh perilaku orang tua atau pernyataan nasihat yang bersifat

verbal

Nurudin, 2014: 47-49)

\section{METODE}

1. Rancangan / Pendekatan

Penelitian

Metode yang digunakan dalam penelitian ini adalah metode penelitian kualitatif dengan paradigma deskriptif interpretatif. Metode penelitian ini merupakan tradisi Sosiologi dan Antropologi, akan tetapi menjadi bagian penting dalam penelitian komunikasi. Metode kualitatif untuk penelitian komunikasi juga dapat dilakukan dengan paradigma fenomenologi yang sering disebut sebagai paradigma interpretatif. Dalam paradigma tersebut dijelaskan bahwa realitas sosial yang ditunjukkan oleh interaksi sosial yang secara esensial adalah dasar dari komunikasi, bukan saja menampakkan fenomena lambang atau bahasa yang digunakan, tetapi juga menampakkan komunikasi interpersonal di antara anggota-anggota sosial tersebut.

2. Teknik Pemilihan Informan

Sampel dalam penelitian ini diperoleh dengan metode purposive sampling dengan informan mahasiswa Jurusan Ilmu 
Komunikasi, Fakultas Ilmu Sosial

dan Ilmu Politik, Universitas

Jenderal Soedirman, Purwokerto.

Kriteria informan adalah mahasiswa yang berasal dari daerah eks Karesidenan Banyumas, Jawa Tengah, Jawa Barat, dan Mahasiswa yang berasal dari luar pula Jawa.

3. Sumber dan Teknik Pengumpulan Data

Data primer diperoleh secara langsung melalui daftar pertanyaan yang diberikan kepada informan, kemudian informan menceritakan pengalamannya melalui catatan tertulis.

Pengumpulan data dilakukan dengan cara membagi daftar pertanyaan tentang pemahaman informan terhadap makanan tradisional daerahnya dan menjelaskan fungsi komunikasi dari makanan tradisional tersebut.

4. Analisis Data

Data dalam penelitian ini adalah data kualitatif, yaitu berupa gejala sosial, pernyataan, gerakan nonverbal yang dapat direkam oleh deskripsi kalimat maupun gambar, maka analisis data dilakukan dengan menggunakan model alur analisis data Miles dan Hubermas yang meliputi: (1) Reduksi Data, (2) Penyajian Data, dan (3) Penarikan Kesimpulan atau Verifikasi.

Reduksi data merupakan proses pemilihan dan transformasi data kasar yang muncul dari catatan di lapangan. Data kualitatif yang diperoleh kemudian disederhanakan melalui seleksi, meringkas, menguraikan, dan menggolongkan dalam satu pola.

Penyajian data adalah kegiatan menyusun sekumpulan informasi yang akan digunakan dalam penarikan kesimpulan. Cara menyajikan data dengan menampilkan teks naratif maupun tabulasi.

Penarikan kesimpulan atau verifikasi merupakan tinjauan atau pemikiran ulang tentang catatan di lapangan. Makna-makna yang muncul dari data harus diuji kebenarannya, kecocokannya, dan kekokohannya sehingga membentuk validitas. Data yang disajikan secara narasi dan tabel kemudian dinterpretasikan dan diuji validitasnya dengan mencocokan data melalui informan maupun teori yang mendukung.

5. Waktu dan Lokasi Penelitian 


\section{MAKNA KOMUNIKASI DI BALIK MAKANAN TRADISIONAL}

Penelitian dilakukan selama 4

( empat ) bulan. Mulai dari pemilihan

informan, pengisian jawaban

pertanyaan, sampai analisis data.

Penelitian dilakukan di kampus

Fakultas Ilmu Sosial dan Ilmu

Politik, Universitas Jenderal

Soedirman, Purwokerto.

\section{E. HASIL DAN PEMBAHASAN.}

1. Profil Informan

Informan berasal dari daerah

eks Karesidenan Banyumas, yaitu

Cilacap, Banyumas, Purbalingga, dan

Banjarnegara, Jawa Tengah, Jawa

Barat, Jawa Timur dan daerah luar

Jawa yang diwakili oleh informan

dari Sumatera Utara dan Sumatra

Barat. Masing-masing informan mendeskripsikan makanan

tradisional serta menjelaskan makna

dan fungsi komunikasi dari makanan tersebut.

2. Makanan Tradisional Banyumas

Banyumas memiliki makanan tradisional yang sangat khas, seperti mendoan dan getuk goreng. Selain kedua makanan tersebut, Banyumas juga memiliki berbagai ragam makanan tradisional yang khas di masing-masing kabupaten di wilayah Eks Karesidenan Banyumas. Salah satu makanan tradisional khas daerah di Desa Sudimara, Kecamatan

Cilongok, Banyumas adalah Cimplung. Makanan ini termasuk jajanan tradisional yang bahan utamanya singkong, gula merah, air, dan daun pandan. Cimplung dimasak dengan cara direbus, dan biasanya disajikan bersama kopi atau teh hangat.

Menurut informan Maulida Adistri, Cimplung berasal dari kata "cemplung" yang dalam bahasa Banyumasan berarti memasukkan ke dalam air. Singkong sebagai bahan dasar dianggap sebagai bentuk kesederhanaan dan sikap apa adanya masyarakat Banyumas. Walaupun sederhana dan biasa saja, rasa manis dari gula dianggap sebagai bentuk kebahagiaan dalam kehidupan yang sederhana. Makna komunikasi sosial cimplung adalah mengajarkan bahwa utntuk hidup senang tidaklah harus bermewah-mewahan.

Banyumas, seperti halnya daerah lain di Jawa Tengah, juga memiliki makanan khas Bubur Abang Putih ( Bubur Merah Putih). Bahan baku bubur ini adalah beras putih, air, santan, gula jawa, daun pandan, dan garam. Proses pembuatan diawali dengan perebusan beras putih dengan air yang 
dicampur santan, garam, dan daun pandan sembari diaduk hingga menjadi bubur. Setelah membubur, sebagian diangkat untuk mendapatkan bubur putihnya. Setelah bubur putih dipisahkan, bubur yang masih dimasak dalam panic ditambahkan sisiran gula jawa, lalu diaduk agar menjadi merah. Setelah masing-masing bubur masak, kemudian dituangkan kedalam takir yang terbuat dari daun pisang. Cara penyajian bubur abang putih di Banyumas adalah bubur merah dengan takaran yang lebih banyak dituangkan pada bagian bawah, dan bubur putih dengan jumlah yang lebih sedikit pada bagian atasnya.

Menurut informan Chistopher Liando, dengan bubur abang putih dan upacara slametan, masyarakat tradisional Jawa menunjukkan keyakinan akan adanya Tuhan yang memberi kehidupan dari bibit atau darah merah dan putih ayah ibunya. Penyajian bubur merah dan putih dalam satu wadah menyimbolkan sperma yang bertemu sel telur sehingga menghasilkan seorang bayi. Halus dan manisnya bubur mengandung makna keinginan orangtua bayi agar kelak kehidupan anaknya mulus dan tidak bernasib pahit.

Bubur abang putih yang erat pemaknaannya dengan proses terbentuknya seorang bayi digunakan untuk menyampaikan pesan berita kelahiran kepada sanak saudara dan tetangga. Saat ini di daerah Banyumas bubur abang putih tetap menjadi makanan tradisional yang khas dan simbol berkat dari keluarga yang menamai anak bayinya. Sedangkan dalam perspektif transcendental, bubur merah putih mengandung pesan penghormatan, ucapan syukur, serta permohonan kepada Sing Gawe Urip atau Tuhan Sang Pencipta.

Makanan tradisional yang dianggap sebagai ikon Banyumas adalah Mendoan dan Gethuk Goreng Sokaraja. Mendoan merupakan makanan khas Banyumas yang terbuat dari tempe yang diolah dengan adonan tepung dan bumbubumbu, kemudian digoreng setengah matang. Menurut informan Sri Wahyuni, mendoan telah mencirikan budaya kelompok masyarakat Banyumas dan sekitarnya. Masyarakat di Banyumas menganggap mendoan sebagai 


\section{MAKNA KOMUNIKASI DI BALIK MAKANAN TRADISIONAL}

makanan yang mengungkapkan

ikatan sosial dan kekeluargaan.

Fungsi mendoan bagi

masyarakat Banyumas adalah sebagai camilan atau lauk makan.

Sedangkan bagi wisatawan yang berkunjung ke Banyumas, mendoan menjadi ikon makanan khas sebagai oleh-oleh. Mendoan memiliki fungsi sebagai sarana komunikasi tradisional, yakni untuk mengakrabkan rasa kekeluargaan. Disajikan pada saat masih hangat, mendoan dimaknai untuk menghangatkan suasana ketika terjadi percakapan keluarga. Tempe mendoan yang dimaknai juga dengan "mendo-mendo", memiliki fungsi tersirat sebagai sarana komunikasi dengan orang lain serta sarana untuk membaur bersama orang lain.

Gethuk goreng merupakan makanan tradisional yang terbuat dari singkong yang dibumbui gula merah, dikukus bersama gula merah lalu ditumbuk, dan selanjutnya digoreng. Bentuk gethuk goreng bisa bulat, ada juga yang lonjong, sebesar telur ayam kampung. Jajanan tradisional ini sudah terkenal, terutama bagi wisatawan yang melintasi wilayah Sokaraja, Kabupaten Banyumas. gethuk goreng menjadi oleh-oleh yang khas, dan dapat dijumpai di sepanjang jalan raya di Sokaraja.

Gethuk goreng sangat tepat jika dinikmati bersama secangkir kopi atau teh. Rasanya sangat khas, manis gula merah dan gurihnya singkong. Kini gethuk goreng dipasarkan dengan berbagai varian rasa untuk memenuhi selera wisatawan, seperti rasa durian, vanilla, dan coklat.

Menurut informan Tiara Rahmadanty, gethuk goreng diciptakan secara tidak sengaja pada tahun 1918 oleh Sanpirngad, seorang penjual nasi keliling di Sokaraja. Saat itu gethuk yang dijualnya tidak laku, sehingga mencari cara bagaimana agar masih bisa dikonsumsi. Gethuk yang tidak laku terjual pada hari itu kemudian digoreng dan dijual lagi. Ternyata makanan baru tersebut digemari oleh para pembeli. Tidak sedikit para pejuang kemerdekaan yang singgah di warung Sanpirngad, sehingga produknya makin dikenal banyak orang.

Sanpirngad kemudian mulai menjalankan bisnis gethuk gorengnya di Sokaraja. Selanjutnya, bisnis gethuk goreng itu dia wariskan 
kepada menantunya Tohirin. Di

tangan Tohirin inilah gethuk goreng mencapai puncak kejayaan. Hingga saat ini, beberapa toko genthuk goreng sudah dikelola oleh anak cucu Tohirin. Jika melintasi Sokaraja yang terletak sekitar tujuh kilometer dari kota Purwokerto, dapat dijumpai banyak toko oleh-oleh gethun goreng yang menampilkan merek Tohirin. Gethuk goreng yang saat ini dijual bukan lagi gethuk yang tidak laku dijual, namun sengaja dibuat untuk digoreng.

\section{Makna filosofi dan}

komunikasi gethuk goreng adalah sebagai simbol keserhanaan, nrimo ing pandum, apa adanya. Gethuk goreng mengajarkan kepada manusia untuk tidak berputus asa dan selalu berusaha untuk yang terbaik. Gethuk goreng dapat dimanfaatkan sebagai media komunikasi bagi keluarga saat berkumpul, atau sebagai teman mengobrol bagi tamu yang datang.

3. Makanan Tradisional Kebumen

$$
\text { Kabupaten Kebumen, Jawa }
$$

Tengah memiliki makanan tradisional yang khas, yaitu Lanthing. Menurut informan Chandra Demis, banyak sumber yang mengatakan lanthing berasal dari daerah Lemahduwur, sebuah desa yang bermakna tanah yang tinggi, karena memang terletak di dataran tinggi. Daerah tersebut merupakan sentra perajin lanthing. Saat ini industri kecil lanthing terus berkembang dan tersebar di sejumlah kecamatan di Kabupaten Kebumen.

Lanthing merupakan jenis makanan tradisional berupa gorengan atau kerupuk yang berbahan baku singkong berkualitas. Bahan bumbunya sangat sederhana, yaitu terdiri dari bawang putih, ketumbar, dan garam. Kekhasan lanthing dari daerah Kebumen adalah bentuknya yang menyerupai angka 8 ( delapan). Awalnya lanthing hanya berwarna merah dan putih serta memiliki satu jenis varian rasa original. Seiring dengan perkembangan jaman, lanthing mengalami banyak perubahan dari varian rasa, seperti rasa bawang, pedas, pedas manis, Lombok hijau, jagung bakar, dan keju.

Makanan tradisional lanthing layak untuk dipertahankan, karena industri kecil ini menopang ekonomi keluarga serta sebagai sarana untuk melestarikan tradisi dan budaya yang telah diwariskan secara turun temurun. Bahan bakunya juga mudah tersedia di daerah sekitar. Lanthing 


\section{MAKNA KOMUNIKASI DI BALIK MAKANAN TRADISIONAL}

memiliki makna komunikasi dan filosofi Jawa, karena bentuknya yang menyerupai angka 8 ( delapan). Angka delapan menurut kepercayaan masyarakat Jawa merupakan angka yang baik, karena alurnya tidak terputus. Angka ini juga dipercaya sebagai kehidupan yang berkelanjutan dan tidak terputus di tengah jalan serta memberikan sebuah identitas daerah.

\section{Makanan Tradisional Salatiga}

Salah satu makanan khas kota Slatiga, Jawa Tengah, adalah entingenting atau dikenal juga dengan nama enting-enting gepuk. Rasanya dominan manis dengan sedikit rasa gurih menonjol yang berasal dari kacang. Tekstur enting-enting terlihat padat membentuk seperti prisma utuh. Jika digigit maka prisma tersebut akan hancur dan menyisakan remah-remah halus perpaduan gula dan kacang. Enting-enting gepuk tidak dapat bertahan terlalu lama. Setelah proses pembuatan, entingenting hanya bertahan selama enam bulan. Saat ini enting-enting sudah menjadi makanan tradisional ikon kota Salatiga, di kaki Gunung Merbabu ini.

Sejarah enting-enting tidak terlepas dari bangsa dan etnis
Tionghoa. Informan Arum Widayatni menyebutkan, enting-enting gepuk ditemukan oleh Khoe Tjong Hok yang berasal dari Fukkian, China. Pertama kali dibuat tahun 1920 di sebuah klenteng Hok Tek Bio yang ada di Salatiga. Diproduksi secara sederhana sampai tahun 1960, enting-enting menggunakan kemasan klobot ( kulit daun jagung yang dikeringkan). Pemasarannya pun masih sederhana, dari kampung ke kampung dan pasar tradisional, serta belum memiliki merek dagang.

Tahun 1971 Khoe Tjong Hok mendirikan toko pertama yang menjual enting-enting gepuk. Kemudian diteruskan oleh generasi selanjutnya, yaitu Khoe Djioe Nio. Kini enting-enting gepuk sudah menjadi ikon makanan tradisional Salatiga. Wisatawan yang berkunjung ke Salatiga menjadikan enting-enting sebagai jajanan wajib yang harus dibeli.

Makna sosial budaya entingenting terletak pada proses pembuatannya. Enting-enting dianggap sebagai penanda sejarah etnis Tionghoa di Salatiga. Proses produksinya juga membutuhkan banyak tenaga kerja, sehingga sangat membantu perekonomian warga 
sekitar. Rasa cinta terhadap makanan tradisional dan upaya untuk melestarika makanan tradisional juga dibuktikan dengan masih bertahannya enting-enting di tengah beragam makanan impor. Entingenting dapat dula dipandang sebagai simbol terjadinya komunikasi lintas budaya antara masyarakat lokal dengan etnis Tionghioa.

5. Makanan Tradisional Jawa Timur Jawa Timur memiliki banyak makanan tradisional yang khas, seperi Rujak Cingur, Rawon, Soto Lamongan, dan sebagainya. Namun ada salah satu makanan tradisional yang nama dan bentuknya juga hampir sama dengan daerah lain di Indonesia, yaitu Cenil, makanan tradisional yang berbahan baku tepung singkong, kelapa parut, dan gula. Menurut informan Arlita Wulandari, makanan ini banyak ditemui di pasar-pasar, sehingga disebut sebagai jajanan pasar. Cenil berasa manis dengan tekstur kenyal dan agak lengket. Bentuknya bervariasi, ada yang lonjong, bulat, dan persegi. Warnanya pun beraneka ragam dan biasanya satu porsi dibuat lebih dari satu warna. Cenil biasanya diberi taburan parutan kelapa dicampur gula pasir atau gula jawa.
Menurut filosofinya, cenil bersifat lengket dan sulit untuk dipisahkan yang merepresentasikan bahwa orang Jawa memiliki sifat persaudaraan yang sangat erat dan sulit untuk memecahbelah persaudaraan mereka. Pesan komunikasi nonverbal yang ingin disampaikan pada makanan cenil ini yaitu, bahwa kita harus selalu bersyukur walaupun terkadang apa yang kita inginkan tidak selalu tercapai. Pada masa silam, misalnya, masyarakat Pacitan kesulitan mendapatkan beras, sehingga mengolah tepung kanji sebagai makanan yang disebut cenil itu.

Nama kue cenil menurut informan lain, Siti Nafsul Mutmainah, juga mengandung pesan menggoda, karena konon berasal dari kata "centil" yang berarti menggoda para peminat makanan yang berwarna-warni itu. Cara menyantap makanan cenil ini juga mengandung pesan komunikasi transendental berupa rasa syukur manusia kepada Tuhan. Cenil biasanya dimakan dengan menggunakan pincuk, yang merupakan singkatan pinten - pinten cukup, atau seberapa pun cukup. Sebuah ungkapan rasa syukur atas nikmat yang diberikan Tuhan. 


\section{MAKNA KOMUNIKASI DI BALIK MAKANAN TRADISIONAL}

6. Makanan Tradisional Jawa Barat

Propinsi Jawa Barat memiliki

banyak makanan tradisional yang khas dari daerah atau masing-masing kabupaten. Salah satunya adalah Batagor, yang merupakan akronim dari bakso, tahu, goreng. Makanan ini pada awalnya merupakan kuliner khas kota Bandung. Namun kini Batagor sudah menjadi makanan identitas Jawa Barat. Citarasanya gurih, enak di lidah, dan bumbu kacangnya yang pedas menjadikan Batagor nikmat untuk disantap.

Batagor, menurut informan Rahmat Faturohmah lahir dari ketidaksengajaan yang dilakukan penjual bakso tahu bernama Isan. Saat itu Isan berjual keliling di seputar Jalan Kopo, Bandung. Suatu ketika bakso yang dijajakan Isan kurang laku. Kemudian muncul ide untuk menggoreng sisa bakso. Di luar perkiraannya, ternyata peminat bakso tahu yang digoreng lebih banyak daripada peminat bakso tahu biasa. Akhirnya Isan lebih banyak mengembangkan bakso tahu yang digoreng, dengan memberikan aroma rasa ikan lebih kuat dan lebih banyak serta bumbu kacang. Sejak saat itu bakso tahu goreng Isan dikenal sebagai Batagor. Tahun 1980 muncul nama-nama besar dalam bisnis kuliner Batagor di Bandung, seperti Batagor Riri, Batagor Abuy, Batagor Kingsley, dan Batagor Burangrang. Dalam kiprahnya, tanggal 1 Januari 2015 Khalifah Insan Madani Center meluncurkan produk khas daerah atau lebih tepatnya produk kuliner khas Bandung, yaitu Krupuk Batagor. Merek dagangnya adalah "ngaBandunganBatagor", yang mengandung filosofi "ngabandungan" atau "mendengarkan". Hal tersebut dapat diartikan sebagai merespon apa yang diinginkan oleh pasar terhadap makanan khas berupa camilan.

Jawa Barat juga meiliki makanan khas dari daerah Kabupaten Ciamis yang bernama Galendo. Makanan khas ini berupa camilan yang biasa disajikan sebagai makanan ringan atau makanan penutup. Galendo disebut juga Balendo atau "tahi minyak" adalah residua tau ampas hasil pemasakan santan kelapa dalam proses pembuatan minyak goreng secara tradisional. Galendo berwarna coklat atau coklat tua, berbentuk gumpalan padat dan lembut dengan rasa khas yang enak dan sedikit manis. Galendo dapat diolah lebih lanjut 


\section{MAKNA KOMUNIKASI DI BALIK MAKANAN TRADISIONAL}

menjadi camilan yang menyerupai dodol dengan melakukan pemadatan dan sedikit penambahan gula agar lebih manis.

Menurut informan Ana Tresnawati yang berasal dari Ciamis, Galendo memiliki makna dalam kehidupan sosial budaya, yaitu untuk memanfaatkan ampas dari olahan minyak goreng menjadi olahan makanan yang bisa dikonsumsi agar tidak mubazir. Galendo juga memiliki makna dalam kehidupan sosial budaya sebagai identitas khas kota Ciamis. Makna lain Galendo adalah menjaga keharmonisan dengan keluarga, teman, maupun orang di sekitar, karena Galendo memiliki filosofi " ngobrol dengan akrab".

\section{Makanan atau kuliner} tradisional khas Jawa Barat yang lain adalah Burayot. Berbentuk kue dan berbahan dasar tepung beras yang dicampur dengan gula merah yang dicairkan. Burayot banyak ditemukan di Kecamatan Leles dan Kecamatan Kedungora, Kabupaten Garut. Jajanan ini memang kalah terkenal dengan Dodol Garut, karena Burayot hanya dijual di pasar-pasar tradisional.
Sejarah kue Burayot, menurut informan Nur Fadillah F., karena bentuknya yang menggantung atau dalam bahasa Sunda disebut ngagayot. Banyak yang mengatakan kue ini mirip dengan bentuk alat vital. Namun sampai saat ini tidak diketahui dengan pasti alasan lain mengapa kue ini diberi nama Burayot.

Makna komunikasi kue Burayot sebagai makanan khas Garut adalah sebagai sarana pemersatu atarsaudara atau tetangga, karena kue ini wajib disuguhkan ketika Lebaran. Mengobrol dan menikmati udara dingin Garut akan lebih lengkap jika ditemani sepiring kue Burayot.

7. Makanan Tradisional Sumatera Utara

Kue Bangkit atau kue Bangket merupakan kue tradisional khas Melayu. Kue ini bisa dengan mudah ditemukan di daerah-daerah Sumatera, khususnya Sumatera Utara, Jambi, Riau, dan Kepulauan Riau. Warna kue Bangkit putih kekuningan atau kecoklatan jika diberi jahe. Biasanya kue Bangkit diberi noktah berwarna merah, hijau, atau kuning. Tekstur kue Bangkit keras, namun halus dan gampang remuk. Kue Bangkit akan langsung 


\section{MAKNA KOMUNIKASI DI BALIK MAKANAN TRADISIONAL}

lumer di dalam mulut, karena

berbahan dasar tepung dan

mempunyai rasa yang renyah ketika

dikunyah.

Menurut penuturan informan Nabila Aulia Marpaung, kue ini disebut kue Bangkit karena ukuran kue ini setelah dipanggang mengembang dua kali lipat dari ukuran sebelumnya. Inilah yang membuat orang menyebutnya bangkit atau bangun dan mengembang. Tidak ada yang tahu pasti asal kue ini, namun kue Bangkit sudah ada di kalangan masyarakat Melayu sejak jaman penjajahan Belanda.

Bukan hanya untuk masyarakat pribumi, orang Tionghoa di daerah tersebut juga menjadikan kue Bangkit sebagai slah satu kue khas yang disajikan pada saat perayaan Tahun Baru Imlek. Di sini terjadi akulturasi budaya yang erat dan harmonis antara etnis Melayu dan Tionghoa. Boleh dikatakan, kue Bangkit bermakna mengharmoniskan dua etnis yang berbeda.

\section{Makanan Tradisional Sumatera Barat}

Rendang bagi masyarakat Indonesia bukan merupakan hal yang asing lagi. Masakan khas
Minangkabau ini dapat dijumpai hampir di seluruh wilayah tanah air lewat rumah makan Padang. Bahkan rendang sudah terkenal di beberapa negara di dunia. Makanan yang terbuat dari daging sapi dengan adonan santal yang mengental ini hampir dapat diterima oleh lidah masyarakat di Indonesia. Rendang pun telah menjadi makanan ikonik daerah Sumatera Barat.

Mengutip pendapat Gusti Anan, sejarawan dari Universitas Andalas Padang, informan Muhammad Arviandi Hakim menjelaskan, bahwa rendang sudah mulai dikenal sejak abad ke-16. Hal ini berdasarkan catatan literatur yang menyebutkan masyarakat Minang darat sering bepergian menuju selat Malaka hingga Singapura. Perjalanan tersebut mereka lalui dengan jalur air dan bisa memakan waktu sekitar satu bulan. Para perantau ini tentu sudah menyiapkan bekal makanan karena tidak adanya perkampungan di sepanjang perjalanan, dan bekal makanan itu diduga adalah rendang. Catatan sejarah rendang juga dapat ditemukan dalam catatan harian Kolonel Stuers yang pada tahun 1827 menulis tentang kuliner dan sastra. Dalam catatan tersebut muncul 
catatan makanan yang dihitamkan dan dihanguskan, yang secara implicit mengarah pada rendang. Menurut informan yang mengutip Gusti Anan, hal tersebut merupakan metode pengawetan yang biasa dilakukan masyarakat Minangkabau. Sedangkan rendang berasal dari kata "merandang", yakni memasak santan hingga kering perlahan.

Rendang memiliki posisi terhormat dalam budaya masyarakat Minangkabau serta memiliki makna dan filosofi musyawarah dan mufakat yang secara simbolik digambarkan melalui empat bahan pokoknya. Dagiang atau daging sapi merupakan lambang dari Niniak Mamak, yaitu para pemimpin adat. Karambia atau kelapa adalah lambang Cadiak Pandai atau kaum intelektual. Bahan Lado atau cabai menggambarkan Alim Ulama yang pedas dan tegas dalam mengajarkan syariat agama. Sedangkan Pemasak atau bumbu-bumbu merupakan simbol keseluruhan masyarakat Minangkabau.

Tradisi Minangkabau mengisyaratkan rendang sebagai hidangan yang wajib disajikan dalam acara istimewa, seperti upacara adat, kenduri, atau menyambut tamu kehormatan. Fungsi komunikasi makanan rendang adalah sebagai identitas khas Tanah Minang. Secara simbolik komunikasi sosial di masyarakat Minangkabau juga tergambar dari unsur-unsur bahan baku pembuatan rendang, yang menjelaskan posisi dan peran masing-masing dalam komunikasi.

\section{F. KESIMPULAN DAN SARAN}

1. Kesimpulan

Indonesia memiliki beragam makanan tradisional yang sampai saat ini masih dapat dijumpai di berbagai daerah. Banyaknya makanan import dari negara lain, tidak menjadikan makanan tradisional dilupakan atau ditinggalkan masyarakat.

Makanan tradisional di beberapa daerah memiliki makna yang beragam, mulai sebagai bentuk ritual siklus kehidupan manusia, sebagai simbol persaudaraan, serta makna akulturasi dua budaya yang berbeda.

\section{Saran}

Perlu dilakukan penelitian lanjutan tentang makna komunikasi di balik makanan tradisional dari berbagai daerah lain di Indonesia. Mempertahankan makanan 


\section{MAKNA KOMUNIKASI DI BALIK MAKANAN TRADISIONAL}

tradisional dengan cara mengenalkan sejak dini kepada masyarakat tentang keberadaan makanan tradisional atau dengan cara mengadakan festival makanan tradisional secara berkesinambungan di berbagai daerah.

\section{DAFTAR PUSTAKA}

Aryanti, Ni Nyoman Sri dan I Nyoman Tri Sutaguna. 2016. "Strategi Menjadikan Rumput Laut sebagai Branding Kuliner di Pantai Pendawa, Desa Kutuh, Kabupaten Badung”. Jurnal Analisis Pariwisata. $16,(1), 16-22$.

Chusmeru.2009. "Potensi Wisata Kuliner Kabupaten Banyumas". Jurnal Analisis Pariwisata. 9, (1),87-92.

Malagina, Agni. (2008, April). "Dari Istana Hingga Lapak Margonda". Jurnal Pendar Pena. 14-16. http://www.academia.edu/8800 041/Jurnal_PendarPena_No_V _April_2008_Tema_Kuliner_ Makanan_.Diakses 16 Oktober 2017.
Mapandin, Wahida Y. 2006.

"HUbungan Faktor - Faktor

Sosial Budaya dengan

Konsumsi Makanan Pokok

Rumah Tangga pada Masyarakat di Kecamatan Wamena Kabupaten Jayawijaya Tahun 2005".Tesis pada Program Pasca Sarjana, Universitas Diponegoro: Tidak Diterbitkan

Mulyana, Deddy. 2013. Ilmu Komunikasi Suatu Pengantar. Penerbit PT Remaja Rosdakarya: Bandung Murwani, Endah. 2012. "Eating Out Makanan Khas Daerah: Komoditas Gaya Hidup Masyarakat Urban". Prosiding pada Seminar Nasional Menggagas Pencitraan Berbasis Kearifan Lokal, Jurusan Ilmu Komunikasi Fisip Unsoed. Purwokerto.

Ngalimun. 2017.Ilmu Komunikasi

Sebuah Pengantar Praktis. Pustaka Baru Press: Yogyakarta Nurhayati, Endang. 2013. "Inventarisasi Makanan Tradisional Jawa Serta Alternatif Pengembangannya". Laporan Akhir Penelitian Guru Besar. 
MAKNA KOMUNIKASI DI BALIK MAKANAN TRADISIONAL

Universitas Negeri Yogyakarta:

Yogyakarta: Tidak Diterbitkan.

Nurudin. 2014. Sistem Komunikasi

Indonesia.

RajaGrafindo

Persada: Jakarta

Putri, Ida Ayu Trisna Eka dkk.2010.

"Eksistensi dan Esensi Makanan
Tradisional

Bali

sebagai

Penunjang Culinary Tourism di

Kabupaten Badung". Jurnal

Analisis Pariwisata. 10, (1), 97-

104. 